\title{
The Use of Zeatin to Initiate in Vitro Cultures of Vaccinium Species and Cultivars
}

\author{
Barbara M. Reed' \\ National Clonal Germplasm Repository, U. S. Department of Agriculturel \\ Agricultural Research Service, 33447 Peoria Road, Corvallis, OR 97333
}

\author{
Ana Abdelnour-Esquive1 ${ }^{2}$ \\ Department of Botany and Plant Pathology, Oregon State University, \\ Corvallis, OR 97331
}

Additional index words. blueberry, cranberry, cytokinin, lingonberry, micropropagation, germplasm, tissue culture

\begin{abstract}
Explants of mature pot-grown Vaccinium corybosum L. cultivars were tested for initiation of new shoots using two growing conditions and four cytokinin treatments. Initiation tests with 12 genotypes showed significantly higher rates of new shoot growth on modified woody plant (MWPM) medium with 4 mg zeatin/liter at 25C under low light intensity than on any other treatment. Explants at $25 \mathrm{C}$ in light with 10 or $15 \mathrm{mg} 2 \mathrm{iP} /$ liter initiated at a moderate rate, but significantly lower rates were found for all controls and at $4 \mathrm{C}$ in darkness. To determine the utility of zeatin for initiation of diverse genotypes, 96 Vaccinium accessions from the National Clonal Germplasm Repository, representing 22 species and 44 cultivars, were screened using 25C and low light intensity. Initiation rates higher than $60 \%$ were achieved for 89 of 96 accessions tested. Chemical name used: N6-[2-isopenteny1] adenine (2iP), 6-[4-hydroxy-3-methylbut-2-eny1amino]purine (zeatin).
\end{abstract}

The National Clonal Germplasm Repository in Corvallis, Ore., maintains a collection of $>600$ Vaccinium accessions. To develop a backup in vitro collection encompassing the variability of the genus, standard conditions must be determined for successful initiation and growth of a wide range of species and cultivars. Usually only two plants of each genotype are available for explants, so high rates of initial shoot growth are important in culture establishment. Tissue culture propagation methods for some Vaccinium spp. and cultivars have been described in the literature (Chandler and Draper, 1986; Cohen, 1980; Frett and Smagula, 1983; Hosier et al., 1985; Lyrene, 1980; Nickerson, 1978; Orlikowska, 1986; Scorza et al., 1984; Wolfe et al., 1983; Zimmerman and Broome, 1980),

Received for publication 20 July 1990. The cost of publishing this paper was defrayed in part by the payment of page charges. Under postal regulations, this paper therefore must be hereby marked advertisement solely to indicate this fact.

'To whom reprint requests should be addressed. ${ }^{2}$ Present address: CATIE, Turrialba, Costa Rica. but many others have not been studied. In addition, specific reports on methods to initiate new shoot growth from axillary buds of explants are rare.

Some workers routinely use a $4 \mathrm{C}$ dark treatment with $2 \mathrm{iP}$ for initiation of new growth from explants (Orlikowska, 1986). Hu and Wang (1983) recommend low incubation light intensity for initiation of most plants. In a recent study of four highbush blueberries in a growth room, Etcher and Noe (1989) compared mixtures of zeatin and $2 \mathrm{iP}$ for improving shoot initiation. Mixtures of the two cytokinins were less phytotoxic to new explants than $2 \mathrm{iP}$ alone and produced higher initiation rates. In another study, new shoot growth was initiated on only two of 222 uncontaminated explants of V. angustifolium using $2 \mathrm{iP}$ at 49.2 and $22.8 \mu \mathrm{m}$ (Brissette et al., 1990). This lack of new shoot growth can make initiation the limiting step in establishing Vaccinium cultures.

Because published studies of initiation have been limited to a few cultivars and species, more information is needed on conditions that will produce a high level of initial shed growth from explants of diverse collections of germplasm. Our study compared the effects of zeatin and $2 \mathrm{iP}$ and two growing conditions on explants of 12 Vaccinium corymbosum genotypes. The best treatment from the V. corymbosum study was then used to screen a wide range of species and cultivars to determine if the technique could be successfully used by those who manage germplasm collections or work with diverse species.

Explants of 5-year-old screenhouse or shadehouse pet-grown Vaccinium plants were taken in Aug. 1988 and 1989. Stem sections were cut into $5-\mathrm{cm}$ pieces, disinfested with $0.52 \%(\mathrm{v} / \mathrm{v})$ sodium hypochlorite with $1 \mathrm{ml}$ Tween 20/liter (polyoxyethylene sorbitan monolaurate, Sigma, St. Louis) added, shaken on a rotary shaker for 15 rein, and rinsed twice in sterile distilled water for 5 min each time. Stem sections then were cut into $1-\mathrm{cm}$ single node pieces and planted in $16 \times 100$ $\mathrm{mm}$ glass tubes on $5 \mathrm{ml}$ of woody plant medium (Lloyd and McCown, 1980) modified by doubling the $\mathrm{Ca}\left(\mathrm{NO}_{3}\right)_{2}$ concentration (MWPM) and containing either no cytokinin, zeatin at $4 \mathrm{mg} \cdot \mathrm{liter}^{-1}$ or $2 \mathrm{iP}$ at 10 or $15 \mathrm{mg} \cdot$ liter $^{-1}$. The medium was adjusted to $\mathrm{pH}$ 5.2, solidified with $6 \mathrm{~g}$ agar/liter (DifcoBacto, Detroit), and the tubes were capped with Kim Caps (Kimble, Morton Grove, Ill.) and autoclave.

The effect of cytokinins on 12 genotypes of $V$. corymbosum was tested under low light intensity (low light; $10 \mu \mathrm{mol} \cdot \mathrm{m}^{-2} \cdot \mathrm{s}^{-1}, 16-\mathrm{h}$ days, 25C) or in darkness (4C). After 1 month, all cultures were transferred to fresh medium of the original composition and all cultures that had been grown at $4 \mathrm{C}$ were placed at $25 \mathrm{C}$ in low light. Six explants of each of 12 genotypes were used for each of three replications. For screening, six explants each of 84 additional Vaccinium accessions were placed on zeatin-containing medium in low light $\left(10 \mu \mathrm{mol} \cdot \mathrm{m}^{-2} \cdot \mathrm{s}^{-1}, 16-\right.$ $\mathrm{h}$ days, 25C).

Two months after initial culture, the number of explants with new axillary shoot growth was recorded and new shoots were transferred to MWPM with $2 \mathrm{iP}$ at $5 \mathrm{mg} \cdot \mathrm{liter}^{-1}$ in Magenta GA-7 boxes (Magenta Corp., Chicago) for continued growth. Contaminated cultures were discarded and not included in the data analysis. Data were analyzed using the $\mathrm{G}$ statistic as calculated in Sokal and Rohlf (1969). This test is equivalent to the $\mathrm{F}$ test in determining significant treatment differences but is more accurate for the smaller sample sizes used. Factorial analysis and Duncan's multiple range test were run using 
Table 1. Percentage of Vaccinium corymbosum explants exhibiting axillary shoot initiation after 8 weeks of growth under low light intensity at $25 \mathrm{C}$ or in darkness at $4 \mathrm{C}$ and on four cytokinin conditions.

\begin{tabular}{|c|c|c|c|c|c|c|}
\hline \multirow{4}{*}{$\begin{array}{c}\mathrm{NCGR}^{2} \\
\text { no. }\end{array}$} & \multirow[b]{4}{*}{ Cultivar } & \multirow[b]{4}{*}{ Lighty } & \multicolumn{4}{|c|}{ Initiation $\times(\%)$} \\
\hline & & & \multicolumn{4}{|c|}{ Cytokinin $^{\mathbf{x}}\left(\mathrm{mg} \cdot\right.$ liter $\left.^{-1}\right)$} \\
\hline & & & \multirow{2}{*}{$\begin{array}{c}\text { Control } \\
(0)\end{array}$} & \multicolumn{2}{|c|}{$2 \mathrm{iP}$} & \multirow{2}{*}{$\begin{array}{c}\text { Zeatin } \\
(4)\end{array}$} \\
\hline & & & & 10 & 15 & \\
\hline \multirow[t]{2}{*}{226} & Bluejay-83 & + & 41 & 52 & 67 & 81 \\
\hline & & - & 88 & 50 & $47^{*}$ & 93 \\
\hline \multirow[t]{2}{*}{51} & Burlington & + & 23 & 44 & 63 & $100^{* * *}$ \\
\hline & & - & 22 & 31 & 15 & 14 \\
\hline \multirow[t]{2}{*}{78} & Cabot & + & 12 & $78^{* * *}$ & 44 & $59^{*}$ \\
\hline & & - & 17 & 33 & 39 & 33 \\
\hline \multirow[t]{2}{*}{95} & Coville & + & 33 & 50 & 59 & 73 \\
\hline & & - & 23 & 25 & 18 & 33 \\
\hline \multirow[t]{2}{*}{56} & Evelyn & + & 0 & $59 * * *$ & 25 & $80^{* * *}$ \\
\hline & & - & 18 & 20 & 0 & 39 \\
\hline \multirow[t]{2}{*}{91} & Herbert & + & 7 & $64^{* *}$ & $70^{* *}$ & $89 * *$ \\
\hline & & - & 40 & $86^{* *}$ & $63^{* *}$ & 25 \\
\hline \multirow[t]{2}{*}{217} & Northsky & + & 15 & $67^{*}$ & 53 & $71^{*}$ \\
\hline & & - & 19 & 33 & 32 & $65^{*}$ \\
\hline \multirow[t]{2}{*}{312} & O'Neal & + & 56 & 59 & 74 & 78 \\
\hline & & - & 41 & 77 & $88^{* *}$ & 73 \\
\hline \multirow[t]{2}{*}{88} & Pemberton & + & 41 & 65 & 82 & $83^{*}$ \\
\hline & & - & 25 & 24 & 31 & 44 \\
\hline \multirow[t]{2}{*}{68} & Pioneer & + & 19 & 53 & 32 & $63^{*}$ \\
\hline & & - & 20 & 38 & 40 & 36 \\
\hline \multirow[t]{2}{*}{75} & Washington & + & 33 & 43 & 43 & 85 \\
\hline & & - & 29 & 31 & $0^{*}$ & 44 \\
\hline \multirow[t]{2}{*}{35} & $V$. corymbosum & + & 22 & 20 & 14 & $78^{*}$ \\
\hline & & - & 8 & 50 & 0 & 50 \\
\hline
\end{tabular}

${ }^{2}$ Identifying number of the National Clonal Germplasm Repository, Corvallis.

$y_{+}, 10 \mu \mathrm{mol} \cdot \mathrm{m}^{-2} \cdot \mathrm{s}^{-1}$ for $16 \mathrm{~h} \cdot \mathrm{day}^{-1} ;-$, darkness.

'Mean of three replicates of six explants each. Significance is based on the comparison of cytokinin treatments with the control (no hormone) treatment within a cultivar and condition, using the $G$ statistic (Sokal and Rohlf, 1969).

*,****** Significant at $P=0.05,0.01$, or 0.001 , respectively.

Table 2. Mean number of Vaccinium corymbosum explants producing new shoot growth following 8 weeks under two growth conditions on four cytokinin treatments.

\begin{tabular}{|c|c|c|}
\hline \multirow[b]{2}{*}{ Cytokinin } & \multicolumn{2}{|c|}{ Condition $^{\mathbf{z}}$} \\
\hline & 4C, darkness & $25 \mathrm{C}$, light \\
\hline $\begin{array}{l}\text { No cytokinin } \\
\text { 2iP } 10 \mathrm{mg} \cdot \operatorname{liter}^{-1} \\
\text { 2iP } 15 \mathrm{mg} \cdot \operatorname{liter}^{-1} \\
\text { Zeatin }\end{array}$ & $\begin{array}{l}5.0 \mathrm{c}^{\mathrm{y}} \\
6.7 \mathrm{bc} \\
6.0 \mathrm{c} \\
7.5 \mathrm{bc}\end{array}$ & $\begin{array}{r}5.4 \mathrm{c} \\
9.7 \mathrm{~b} \\
9.4 \mathrm{~b} \\
14.1 \mathrm{a}\end{array}$ \\
\hline
\end{tabular}

${ }^{2}$ Mean of 18 explants each of 12 accessions; light $=10 \mu \mathrm{mol} \cdot \mathrm{m}^{-2} \cdot \mathrm{s}^{-1} ; 16 \mathrm{~h} \cdot \mathrm{day}^{-1}$.

${ }^{y}$ Mean separation in columns by Duncan's multiple range test, $P=0.05$. $\mathrm{LSD}=2.8$.

MSTAT software (Michigan State Univ., East Lansing).

The best initiation rates (percentage of explants showing new shoot growth) for the 12 genotypes ranged from $31 \%$ to $100 \%$ for the eight treatments (Table 1). As in other studies (Etcher and Noe, 1989; Zimmerman and Broome, 1980), many differences exist between genotypes. New shoot production depended on the interaction of genotype with cytokinin and growth condition $(P \leq 0.001)$ (data not shown).

The type and concentration of cytokinin significantly affected the rate of initiation in individual cultivars of $V$. corybosum. Eight of 12 genotypes exhibited significantly higher initiation $(P \leq 0.05)$ on medium containing zeatin than on control medium (Table 1). Chandler and Draper (1986) found that zeatin stimulates multiplication in $V$. corym- genotypes responded differently $(P \leq 0.05)$ between the two conditions. with $25 \mathrm{C}$ and low light being better than $4 \mathrm{C}$ in darkness in all cases (data not shown).

Guided by the results of the $12 \mathrm{~V}$. corymbosum genotypes, we screened 84 additional Vaccinium accessions using the most successful treatment, $4 \mathrm{mg}$ zeatin/liter with low light (16-h days, 25 C). Among the 84 accessions tested, the initiation rate of the 22 species included ranged from $23 \%$ to $100 \%$ for the six replicates planted. Nine species were $100 \%$ successful (V. caesariense Mackenzie, V. constablaei A. Gray, V. delavayi Franch., $V$. moupinense Franch, $V$. pallidium Ait., V. parvifolium J.E. Smith, $V$. simulatum Small, V. uliginosum L., and $V$. vitis-idaea L.) and only three species ( $V$. angustifolium Ait., V. myrtilloides Michx., and $V$. sempervirens D. Rayner and J. Henderson cv. Bloodstone) initiated at $<60 \%$. The remaining 10 species displayed intermediate initiation rates $(V$. ashei Reade, $V$. australe Small, V. corymbosum L., V. crassifolium Andr., V. elliottii Chapm., V. myrtillus L., V. ovatum Pursh, V. padifolium Ait., V. smalii A. Gray, and V. stamineum L.).

Individual $V$. corymbosum cultivars also produced a range of initiation rates with 10 of 27 at $100 \%$ (cultivars Bluehaven, Burlington, Crabbe IV, Earliblue, Elizabeth, Grover, Harrison, Jersey, Shirley, and Washington) and only two $<60 \%$ (cultivars Blueray and Bluetta). Intermediate rates were obtained with an additional 15 (cultivars Berkeley, Bluecrop, Bluejay 83, Cabot, Collins, Coville, Croatan, Evelyn, Herbert, Johnson, Laniera, Northsky, Patriot, Pemberton, and Pioneer).

Rabbiteye blueberries (V. ashei Reade cvs. Black Giant, Centurion, Climax, Early May, Owen, Satilla, Ethyl, Suwannee, Tifblue, and Walker) and cranberries (V. macrocarpon Ait. cvs. A.J., Cropper, and Pilgrim) had high initiation levels, with nine of 13 at $100 \%$ and all others $>50 \%$. Two hybrids, 'Avonblue' and 'Sharpblue' (V. cotymbosum $\times V$. ashei and $V$. darrowi), produced new shoots on $50 \%$ of the explants.

These results differ markedly from initiation levels found by Orlikowska (1986) on medium with $15 \mathrm{mg} 2 \mathrm{iP} / \mathrm{liter}$, where only $5 \%$ of 'Bluecrop' ( $75 \%$ on zeatin in the present study), $20 \%$ of 'Jersey' (100\%), and $50 \%$ of 'Herbert' $(83 \%)$ explants grew. Initiation rates found by Etcher and Noe (1989) with higher concentrations of mixtures of zeatin and $2 \mathrm{iP}$ were similar or in some cases much lower than those observed in the present study with low levels of zeatin alone: $67 \%$ of 'Bluecrop' (75\% in the present study), $90 \%$ of 'Bluehaven' (100\%), 35\% of 'Collins' (75\%), and $50 \%$ of 'Earliblue' (100\%). V. angustifolium initiated at a rate of $33 \%$ with zeatin in the present study compared with $0.9 \%$ found by Brissette et al. (1990) on 2iP.

Initiation of explants is often best in early summer when the new growth is slightly hardened but not yet influenced by dormancy (Etcher and Noe, 1989). The timing of the present study indicated that excellent rates 
of initiation are possible at midsummer.

The initiation of new growth on Vaccinum explants is often a limiting step for in vitro culture (Lyrene, 1980; Orlikowska, 1986). Efforts to produce initial growth from explants in one case resulted in successful initiation from only two of $>200$ explants used to multiply a new selection (Brissette et al., 1990). Zeatin at $4 \mathrm{mg} \cdot \mathrm{liter}^{-1}$ and low light intensity initiated new shoot growth and reduced such problems in this study. The high rates of initiation obtained in the screen of species and cultivars indicate that this method is successful for a wide range of Vaccinium germplasm. Because of the great variability within this genus, some species and cultivars would still require further study to optimize multiplication media. Adding zeatin to the Vaccinium initiation medium produced more new shoots, allowed a broad range of genotypes to become established, and reduced the time and labor involved. The high cost of zeatin precludes extensive use as a general growth hormone; however, at low levels, zeatin can be used to initiate explant growth for research and commercial purposes.

\section{Literature Cited}

Brissette, L., L. Tremblay, and D. Lord. 1990. Micropropagation of lowbush blueberry from mature field-grown plants. HortScience 25:349351.

Chandler, C.K. and A.D. Draper. 1986. Effect of zeatin and $2 \mathrm{iP}$ on shoot proliferation of three highbush blueberry clones in vitro. HortScience 21:1065-1066.

Cohen, D. 1980. Application of micropropagation methods for blueberries and tamarillos. Comb. Proc. Intl. Plant Prop. Soc. 30:144-146.

Etcher, T. and N. Noe. 1989. Comparison between $2 \mathrm{iP}$ and zeatin in the micropropagation of highbush blueberry (Vaccinium corymbosum). Acta Hort. 241:185-190.

Frett, J.J. and J.M. Smagula. 1983. In vitro shoot production of lowbush blueberry. Can. J. Plant Sci. 63:467-472.

Hosier, M. A., G. Flatebo, and P.E. Read. 1985. In vitro propagation of lingonberry. HortScience 20:364-365.

Hu, C.Y. and P.J. Wang. 1983. Meristem, shoot tip and bud cultures, p. 177-227. In: D. Evans, W. Sharp, P. Ammirato, and Y. Yamada (eds.). Handbook of plant cell culture, vol. 1. Techniques for propagation and breeding. Macmillan, New York.

Lloyd, G. and B. McCown. 1980. Commerciallyfeasible micropropagation of mountain laurel, Kalmia latifolia, by use of shoot-tip culture. Comb. Proc. Intl. Plant Prop. Soc. 30:421-427.

Lyrene, P.M. 1980. Micropropagation of rabbiteye blueberries. HortScience 15:80-81.

Nickerson, N.L. 1978. In vitro shoot formation in lowbush blueberry seedling explants. HortScience 13:698.

Orlikowska, T. 1986. Micropropagation of highbush blueberry. Fruit Sci. Rpt. 13:105-115.

Scorza, R., W.V. Welker, and L.J. Dunn. 1984. The effects of glyphosate, auxin, and cytokinin combinations on in vitro development of cranberry node explants. HortScience 19:66-68.

Sokal, R.R. and F.J. Rohlf. 1969. Biometry. Freeman, San Francisco.

Wolfe, D. E., P. Eck, and C-K. Chin. 1983. Evaluation of seven media for micropropagation of highbush blueberry. HortScience 18:703-705.
Culture-Applications and Feasibility. U.S. Dept. Agr. Sci. \& Educ. Admin. ARR-NE-11. p. 4447. 